CATALAN REVIEW

Catalan Review

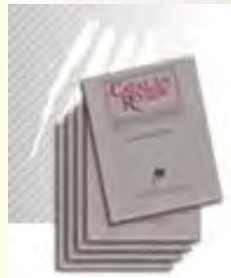

You are accessing the Digital Archive of the Catalan Review Journal.

By accessing and/or using this Digital Archive, you accept and agree to abide by the Terms and Conditions of Use available at http://www.nacs-

catalanstudies.org/catalan_review.html

Catalan Review is the premier international scholarly journal devoted to all aspects of Catalan culture. By Catalan culture is understood all manifestations of intellectual and artistic life produced in the Catalan language or in the geographical areas where Catalan is spoken. Catalan Review has been in publication since 1986 .
NORTH

AMERICAN

CATALAN

SOCIETY
Esteu accedint a l'Arxiu Digital del Catalan Review

A l' accedir i / o utilitzar aquest Arxiu Digital, vostè accepta i es compromet a complir els termes i condicions d'ús disponibles a http://www.nacs-

catalanstudies.org/catalan_review.html

Catalan Review és la primera revista internacional dedicada a tots els aspectes de la cultura catalana. Per la cultura catalana s'entén totes les manifestacions de la vida intel lectual i artística produïda en llengua catalana o en les zones geogràfiques on es parla català. Catalan Review es publica des de 1986.

\title{
Oller and Zola: A Recapitulation Mercè Vidal-Tibbits
}

Catalan Review, Vol. III, number 2 (1989), p. 173-182 


\title{
OLLER AND ZOLA: A RECAPITULATION
}

\author{
MERCÈ VIDAL TIBBITS
}

Much has been written about Oller as a disciple of Emile Zola. Divergent opinions about Oller and naturalism have circulated since this relationship was first recognized in 1882, when Oller published La Papallona.

We will consider in this study the different critics who have adressed this issue, and although it does not pretend to be an exhaustive treatment of the subject, we will try to give an accurate view of what has been said about Oller in relation to Zola and to naturalism.

It is unquestionable that Oller's technique was inspired, in party, by Zola's novels. Oller admitted that around I878, after reading Evangeline by Longfellow and Une Page d'amour, the first of Zola's books which Oller read, he made the decision to write professionally and to do so in his mother tongue, Catalan. According to Oller, it was Une Page d'amour which led him to «discover the large amount of poetry that nature offers to those who know how to observe it" (Memòries 6). Oller's admiration for Zola the novelist was life-long, as we can observe in reading Oller's Memòries literàries. It is well known that the highlight of Oller's trip to Paris in 1886 was meeting with Zola on two occasions.

Oller was dubbed a naturalist soon after he started publishing. The Catalan intellectuals saw in his works a new style of writing, different from the prevailing tendencies and trends in Catalan literature. These intellectuals identified this new style with the French naturalist school. Joan Sardà, a famous Catalan critic of that time and good friend of Oller, was probably the first to label Oller's work as naturalistic, in an article about $L a$ Papallona published in 1882 (Obres, 193). In this Memòries literàries Oller wrote that, in 1883 , a "respected Catalan writer» whose 
name Oller does not mention "considered me an implacable fanatic of the naturalist school, the school based on the observation of reality" (55). This phrase, "the school based on the observation of reality", gives us the central clue to properly interpret why Oller was considered a naturalist by some. Walter Pattison, in El naturalismo español wrote that in the I880s the concept "naturalism» meant different things to different people: some critics considered it to be "the positivistic and materialistic philosophy upon which the experimental sciences are based" (10), but for the majority the word naturalism had a much broader scope: "the intimate imitation of Nature by Art" (9). In this broader scope we can more easily accept the comments of the critics in relation to Oller and naturalism. Sardà's analysis of the technique of $\mathrm{La} \mathrm{Pa}$ pallona in the aforementioned article revealed that for Sardà naturalism was in fact a series of methods used by the realists.

Albert Sabine, another friend of Oller and translator of $\mathrm{La}$ Papallona into French, wrote in $188_{3}$ that La Papallona was "pure naturalism" (Polybiblion). When we consider that a few months later Sabine spoke about "Oller's irreprochable morality" (Les Etapes, 298), it becomes obvious that Sabine's understanding of the concept "naturalism" was not similar to Zola's. For Sabine it meant something very similar to "realism".

When asked to write an introductory letter to the French translation of La Papallona, Zola complied. In this letter, Zola stated very clerly that he did not consider Oller a naturalist: "no and 1000 times no" (rv). Zola insisted: "Our only connection is that the wind of truth that blows in France, also blows in Spain" (v). "Oller is above all a narrator who is moved by his own narration and who carries emotion to the extreme, even at the expense of truth" (Iv).

In this same year, 1885 , Clarín reflected the prevalent interpretation of naturalism in Spain in a letter to Oller. Clarín refered to La papallona as "an oasis novel... sweet, of simple and deep beauty", and then went on to write: "If asked what naturalism is, answer: this novel". (Archivum, si6). 
In 1886, when Felipe B. Navarro published his Spanish translation of La Papallona, he displayed an understanding of naturalism closer to that of Zola. Navarro denied that Oller was a naturalist. He stated in his introduction to this translation: "Although Oller's works are rooted in life's strict reality, his originality comes from his ability to find the poetry that emanates from the reality of life" (x). It would have been difficult for Navarro to represent Oller as a naturalist because Navarro's introduction immediately followed the Spanish version of Zola's introductory letter to La Papallona.

Josep Yxart, considered one of the most responsible and knowledgeable Catalan critics of his time and totally immersed in contemporary European literature, compared the technique of Oller to that of Zola and the French naturalist school better that any other critic. In an article about Vilaniu in 1886, Yxart cited at length the main differences between Oller and Zola; "Oller idolizes reality and understands that the novel is an exact imitation of it. His power of observation is penetrating and he puts his observations on paper with palpitating vigor" $(250)$. " $\mathrm{He}$ has the faculty to evoque in an immediate and positive way the sensations that reality produces" (25I). "But he is not a sensualist, like the French naturalists... because sensations do not influence the conduct and personality of his characters, and this personality does not reside exclusively in the physical temperament" (254). "Oller is not pesimistic or lugubrious, inclined to the pathological or nosological, like the French. In Oller's works passion animates, beautifies, moves and attracts the reader without forming cases for experimental study, contrived and exceptional" (256). "Oller is moved by his own narration and shows, sometimes in indirect ways, the sympathy or disgust which he feels for his characters" (257). In his works Catalunya appears as it really is, and the social classes and their condition are presented as a social study" (262).

But not everybody saw this issue as clearly as Yxart. Numerous critics accused Oller of naturalism in Vilaniu. Even Valera 
called Oller a naturalist, but he clarified: "You are a naturalist in the proper sense and in the way that I enjoy naturalism... Who, in this sense, is not a naturalist?» (Oller, Memòries, 4r).

Inspired by a reading of $L a$ bufetada, in 1890 Yxart defended the literature based on reality, which produced, in his view, an art which was deep and complex, vigorous, advanced in its technique, and which offered "a penetrating and intense exhibition of life" (El año pasado 1890, 134). He did not call Oller's novel or this form of literature in general naturalism, but it is obvious that he thought that the French school was the force behind the powerful literature he was describing. As in his previous article, Yxart acknowledged the indebtness of Oller and all modern literature to naturalism, but he recognized Oller's own distinct personality and style.

In I89I, Joan Sardà focused his analysis of La febre d'or on the similarities and differences between Oller and Zola (Obras). However, in contrast to his earlier statements about La Papallo$n a$, in this article Sardà did not say that Oller was a naturalist. Francisco Muns, in El Correo Catalán, spoke about Oller and La febre d'or in a vein that underlined the realism of Oller's presentation of the individual and of society. Muns' article implied a comparison of the content of La febre d'or with naturalism when he wrote that in this novel ware pictured the vices and deformities of society", but, Muns continued, «in it also appear the virtues that are hidden in its bossom; as a result of this, the morality of the novel is irreprochable" (9).

Jaume Brossa Roger called La febre d'or "an essay on a division of the sociological novel" (354), complaining that the psychology of Oller's characters was not true to life and that the plasticity of the novel, which could have been its main asset, was diluted by the fact that it was achieved by an accumulation of unimportant exterior details, not by uthe exteriorization of the processes of ideas, sensations, emotions and acts of the will" (35s). However, Brossa Roger did not talk about naturalism. The origin of all the concepts that he discussed can be traced back 
to naturalism but, as we see in this and other articles, by this date they had acquired a meaning of their own, independent of the French school that brought them to the center of public attention.

In 1899 , when Oller published La bogeria, naturalism was no longer as prominent as it had been had been fifteen years earlier. Despite this waning of interest, the title of the novel still evoqued images of naturalism. By and large, however, critics avoided the use of this term when discussing La bogeria. They commented on its scientific theme, the "morbid psychology" of the main character, the force of heredity, determinism and other subjects which would have been preceded or closely followed by the word naturalism some years before. Josep Roca i Roca was the only exception, but we cannot avoid wondering what he meant when he said that in this novel Oller was «faithful to the healthy naturalist school" (La Vanguardia). A comment by F. Ripoll summarized the universal judgment on La bogeria: "...this novel is a picture of life and, therefore, one should consider life itself, and not Oller, responsible for the fanaticism and determinism that one might find in its $(\mathrm{r})$. The concept of determinism was not used by Ripoll to imply naturalism but, simply, an accurate vision of the world. Most critics, when talking about the protagonist of La bogeria, recognized a strong parallelism between him and the main character in L'Escanyapobres. For all the labeling of naturalist that was applied to Oller, it was surprising that it did not come after the publication of these two novels, which the modern critics consider closer to our present-day understanding of naturalism than any other of Oller's works.

In 1906 Oller published Pilar Prim, his last novel. It was closer to the so-called psychological novel than his previous works. Sergi Beser called it Oller's response to the crisis of the genre in Europe at the end of the rith century (I5). The novel was praised as one of Oller's best, but this late glory soon disappeared. It was not until Oller's death in 1930 that critics wrote about 
him again. Most of the articles that were published then mentioned the main characteristics of Oller's technique, without adscribing him to any particular school: observation, detail, lack of imagination, psychology of the every-day man, some romanticism, social content, etc., but some critics still described Oller as a naturalist. Joan Puig i Ferreter, for instance, mourned: "Why didn't Oller fall in love with Balzac or Dickens, great imaginations who could have unleashed his, instead of becoming excited about Zola, who could do him no good?" ( $\mathrm{La}$ Veu). The critic Domènec Guansé refered to Oller's technique as naturalistic, but added: "what separates him from naturalism is that in his work there is no previous scientific documentation" ( $\mathrm{La} \mathrm{Pu}$ blicitat).

The new wave of interest in Oller, which has lasted until now, started around 1948, when his complete works were published. But before we look at what has been said about Oller in relation to Zola since then, we will quote the Columbia Dictionary of Modern European Literature, published in 1947: "Oller's characters are photographs taken in a sordid milieu of repugnant characters... In following the French naturalist school Narcís Oller developed marked talent as an observer, although... he frequently presented incarnations of vices and passions rather than men of flesh and blood" (I53-4). But the Dictionary continues surprisingly: "Yet his realism never becomes crude" (IS4), and finishes with a shocking assertion: "... his work is always moralizing and has an essential didactic purpose" (I5s). Obviously, in 1947, a supposedly well documented source still had no clear concept of Oller, nor of naturalism, for that matter.

The volume of Oller's complete works published in 1948 included two critical studies, one by Manuel de Montoliu and one by Maurici Serrahima. In "L'obra de Narcís Oller", which serves as an introduction to the book, Manuel de Montoliu railed vehemently against the "pretended naturalism" of the Catalan author. "It is time", he wrote, "to declare that in Oller's work there are none of the basic characteristics of naturalism, and the- 
refore there is no reason to maintain any longer this error, which does not accomplish anything but distort the true sense of the work of our writer" (xvII). Montoliu was not the first critic to defend that idea, but he was the first one to be heard by everyone, because the book where his article appeared has been read by all the critics of Oller and because Montoliu's opinion was stated in very unambiguous terms. In this same book, Maurici Serrahima expressed a similar opinion: "In regard to this question [Oller's naturalism] I will not even consider the philosophical and moral aspects, because the problem of a deterministic materialism did not exist for Oller. But even limiting ourselves to the literary aspects... it is necessary to agree that Oller's novels and those of Zola have very little in common" (El Món 1463).

Nowadays the study of naturalism and its representatives has shown that the word "naturalism" means different things when applied to different countries and even to different writers. The leading present-day critics of Oller do not consider him a naturalist in the most strict sense of the word. An article written in 1972 by Maurici Serrahima reflects this view: «Realism brought Oller close to naturalism, the fashion at the time" (Dotze 52) but "Oller never shared the positivism and the deterministic materialism which were the 'philosophical' bases of the school. Oller only accepted - and this only up to a certain point - its methods and its literary objectives" (Dotze 60-6I). L'Escanyapobres and La bogeria are the novels of Oller considered to be closest to the modern understanding of naturalism. Alan Yates and Sergi Beser reflect this fact in their introductions to the respective editions of these books, the first one published in 1980, and the other in 1986. Alan Yates writers that L'Escanyapobres «... is the literary product which more perfectly and with the most originality conforms itself to the platonic ideal of a Catalan realismnaturalism" ( 14 ). Sergi Beser underlines the fact that "... at the time when the principles of the 'experimental novel' were being rejected or trascended, Oller wrote a novel whose subject was the basis of that kind of narrative: determinism" (26). Joan J. 
Gilabert's assertion in the conclusion of his study on the works of Oller summarizes the consensus on Oller and naturalism: "We do not believe that don Narcís' literary principles are those of Zola... However, those principles are 'naturalistic' because naturalism is more than the formula of the experimental novel" (264).

In conclusion, Zola and his school are universally recognized as an inspiring force for Oller. The Catalan writer was considered a naturalist in the $1880 \mathrm{os}$, while the true meaning of this concept had not been accurately established in Spain. But as the concept of naturalism became clearer to the critics, most of them no longer used it to describe Oller's work. They recognized, however, that some of the postulates of naturalism are present in Oller's novels and short stories. The growing interest in Oller in the second half of this century has spured the appearance of numerous scholarly articles and books on the Catalan novelist. Now the critics have been able to put aside some of the topics that had been discussed since Oller started writing, naturalism being one of them, to focus on other important aspects of his work that were not explored before. This will lead to a deeper understanding of Oller and of the world he tried to describe: the Catalan bourgeoisie of the end of the rith century.

MERCÈ VIDAL TIBBITS

HOWARD UNIVERSITY

\section{BIBLIOGRAPHY}

AlAs, Leopoldo (Clarín). 1963. Carta II. "Documentos clarinianios». De Sergio Beser. Archivum xII. 507-22.

BESER, Sergi. 1986. "La bogeria. Historia y discusión de una locura anunciada". La locura. De Narcís Oller. Trad. Jordi Marfa. Barcelona: Edicions del Mall. 9-34.

Brossa Roger, Jaume. I892. "Narcís Oller». L'Avenç Iv. I2. 353-57. 
1947. Columbia Dictionary of Modern European Literature. New York, Columbia University Press. I52-I55, 591-592.

GILABERT, Joan J. 1971. "La obra de Narcís Oller y la novelística española del siglo XIX». Diss. Washington U.

Guansé, Domènec. 1930. "Narcís Oller". La Publicitat LII. 17569. 5 .

Montoliu, Manuel de. 1948. "Estudi crític". Obres completes. De Narcís Oller. Barcelona: Editorial Selecta. xIII-xxxIIr.

Muns, Francisco. I893. "La febre d'or, per don Narcís Oller". El Correo Catalán xviII. 5750. 8-9.

Navarro, Felipe B. 1886. "Narciso Oller". La mariposa. De Narcís Oller. Trad. A. Sabine. Barcelona: Daniel Cortezo y Cía., IX-XIII.

Oller, Narcís. 1962. Memòries literàries. Barcelona: Aedos.

Pattison, Walter T. 1969. El naturalismo español. Madrid: Gredos.

Puig i Ferreter, Joan. 1930. "Narcís Oller i la novel.la catalana" $\mathrm{La}$ Veu de Catalunya XL. 10658. 7.

RIPOLL, F. 1899. "Una novela de'n Narcís Oller". La Veu de Catalunya I.19, I-2.

RocA I RocA, Josep. 1899. "La bogeria". La Vanguardia XIX.5650, 4 .

SABINE, Albert. 1885 , Les Etapes d'un naturaliste. Paris: Giraud et Cie., 292-302.

- I883. "Les publications catalanes en I882 (suite)". Polybiblion XxxvIII, 537-44.

SARDÀ, Joan. 19I4. "Narciso Oller. La febre d'om. Obras escogidas. Barcelona: Librería de Fco. Puig y Alfonso, 293-99.

- I9I4. Obres escullides. Barcelona: Fco. Puig y Alfonso.

Serrahima, Maurici. 1972. Dotze mestres. Barcelona: Destino. $45-88$.

- 1948. "El món de Narcís Oller". Obres completes. De Narcís Oller. Barcelona: Selecta. I453-87.

YATES, Alan. 1980. "Pròleg". L'Escanyapobres. De Narcis Oller. Barcelona: Edicions 62, 5-29. 
YXART, Josep. 1890. "El primer trimestre». El año pasado, 1889. Barcelona: Librería Española de López, I25-4r.

- I887. "Narciso Oller. Vilaniu». El año pasado, r886. Barcelona: Daniel Cortezo y Cía., 250-263.

ZoLA, Émile. I886. "Lettre au traducteur". Le Papillon. De Narcís Oller. Trad. Albert Sabine. Paris: Giraud et Cie., I-vII. 